\title{
VALIDITAS LEMBAR KERJA MATEMATIKA SISWA BERBASIS CONTEXTUAL TEACHING AND LEARNING DENGAN PENDIDIKAN LINGKUNGAN
}

\section{THE VALIDITY OF MATHEMATICS STUDENT WORKSHEETS BASED ON CONTEXTUAL TEACHING AND LEARNING WITH ENVIRONEMENTAL EDUCATION}

\author{
Sari Mariana ${ }^{a}$, Putri Yulia ${ }^{b^{*}}$, Nur Rusliah \\ aJurusan Tadris Matematika, Institut Agama Islam Nnegeri (IAIN) Kerinci \\ Jln. Kapten Muradi, Sungai Penuh, sarimariana926@gmail.com

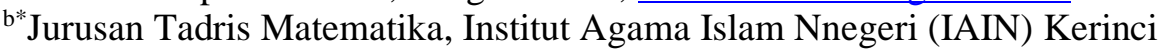 \\ Jln. Kapten Muradi, Sungai Penuh, putriyuliamz@gmail.com \\ ${ }^{c}$ Jurusan Tadris Matematika, Institut Agama Islam Nnegeri (IAIN) Kerinci \\ Jln. Kapten Muradi, Sungai Penuh, nur.rusliah1979@gmail.com
}

\begin{abstract}
ABSTRAK
Bahan ajar yang bisa digunakan dalam pembelajaran hanya buku paket, permasalahan yang ada pada buku paket belum memuat permasalahan mengenai kehidupan sehari-hari sehingga pembelajaran dirasa siswa kurang bermakna dan membosankan. Tujuan penelitian ini adalah untuk menghasilkan dan mengetahui validitas Lembar Kerja Siswa (LKS) berbasis Contextual Teaching and Learning (CTL) dengan Pendidikan Lingkungan yang layak digunakan dalam pembelajaran matematika pada pokok bahasan Himpunan di kelas VII SMPN 4 Sungai Penuh. Metode pengembangan ini menggunakan model ADDIE, penelitian ini terdiri dari 5 tahap yaitu analisis (analysis), perancangan (design), pengembangan dan pembuatan produk (development), implementasi (implementasion), evaluasi (evaluation). Penelitian ini dilakukan di SMP Negeri 4 Sungai Penuh pada kelas VII. Hasil dari penelitian ini menunjukan LKS matematika sudah valid dan layak digunakan berdasarkan sudut pandang pakar, penggunaan LKS pada proses pembelajaran mampu membuat siswa menjadi aktif dan membuat proses pembelajaran berpusat pada siswa.
\end{abstract}

Kata kunci : LKS Matematika, CTL, Pendidikan Lingkungan

\begin{abstract}
The teaching materials that can be used in learning are only textbooks, the problems in the textbooks do not contain problems regarding everyday life so that learning is felt by students to be less meaningful and boring. The purpose of this study was to produce and determine the validity of Contextual Teaching and Learning (CTL) based Student Worksheets (LKS) with Environmental Education which are suitable for use in learning mathematics on the subject of Associations in class VII SMPN 4 Sungai Penuh. This development method uses the ADDIE model, this research consists of 5 stages, namely analysis, design, product development and manufacture, implementation, evaluation. This research was conducted at SMP Negeri 4 Sungai Penuh in grade VII . The results of this study indicate that the mathematical worksheets are valid and feasible to use from an expert point of view, the use of worksheets in the learning process is able to make students active and make the learning process student-centered.
\end{abstract}

Keywords: Mathematics LKS, CTL, Environmental Education 


\section{Pendahuluan}

Matematika adalah salah satu mata pelajaran yang sangat penting di dunia pendidikan terutama pendidikan sekolah, oleh karena itu matematika diajarkan pada setiap jenjang pendidikan di Indonesia mulai dari sekolah dasar sampai sekolah menengah atas bahkan sampai keperguruan tinggi (Setiawan, 2015). Dan dalam dunia pendidikan matematika juga merupakan ratu dari segala ilmu karena jika siswa mempelajari dan mudah memahami matematika maka akan mempermudah siswa untuk mempelajari ilmu lainya seperti, fisika, kimia, sosiologi, kedokteran dan lain sebagainya(Islami \& Rusliah, 2019). Pada umumnya pembelajaran matematika di sekolah menuntut guru untuk melatih dan mengembangkan cara berpikir dan bernalar siswa serta guru diharapakan mempunyai keterampilan baik dalam menggunakan dan mengembangkan model pembelajaran yang kreatif, efektif dan menyenangkan (Yulia \& Ningsih, 2018). Tercantum dalam Peraturan Pemerintah nomor 19 tahun 2005 pasal 20 (Permendiknas, 2007), di isyaratkan bahwa guru diharapakan mengembangkan materi pembelajaran, dimana hal tersebut dipertegas melalui Permendiknas no 41 tahun 2007 tentang standar proses yang antara lain mengatur perencanaan proses pembelajaran yang mensyaratkan bagi pendidik pada satuan pendidikan untuk mengembangkan Rencana Pelaksanaan Pembelajaran (RPP) dan salah satu elemen-elemen dalam RPP adalah bahan ajar.

Usaha meningkatkan kualitas sumber pembelajaran dan hasil pembelajaran harus ada interaksi antara siswa dengan bahan ajar. Tanpa bahan belajar yang memadai sulit diwujudkan proses pembelajaran yang mengarah pada hasil belajar yang optimal, sumber merupakan sarana yang bisa dimanfaatkan guru untuk kepentingan proses pembelajaran, baik sebagian atau keseluruhan dan secara langsung maupun tidak langsung (Sudjana \& Rifai, 2002). Salah satu bahan ajar yang bisa digunakan guru untuk menunjang proses pembelajaran adalah Lembar Kerja Siswa (LKS).

Lembar Kerja siswa (LKS) adalah lembaran-lembaran yang berisi tugas atau soal-soal yang harus dikerjakan siswa yang biasanya berdasarkan urutan langkahlangkah, petunjuk yang telah dirancang sebelumnya dan materi yang dikemas sedemikian rupa agar siswa dapat mempelajari materi tersebut secara mandiri dan dirancang untuk mempermudah proses pembelajaran serta membuat siswa menjadi aktif ikut terlibat dalam materi yang dipelajari serta menuntun siswa 
dalam mencari tahu dan menemukan sendiri suatu konsep.

Namun LKS yang banyak beredar saat ini instan tanpa disertai langkahlangkah yang terstruktur dalam menemukan konsep dasar, LKS hanya berisi materi, contoh, contoh soal dan soal latihan yang berbentuk tes isian (Rawa, 2020). Selama ini beberapa sekolah membeli LKS dari penerbit swasta yang diperjual belikan dan cendrung tidak menarik karena LKS tersebut rata-rata dicetak dikertas buram, cetakan tidak bewarna dan terlihat membosankan serta tidak mampu mendorong siswa untuk tertarik mempelajarinya (Fatimah \& Purba, 2018).

LKS yang biasa dipakai hanya cetakan penerbit yang berisi ringkasan materi secara singkat, contoh soal dan latihan tanpa adanya menghubungkan materi yang dipelajari dengan kehidupan sehari-hari yang membuat proses pembelajaran kurang bermakna (Hanifah, 2017). Padalhal sebenarnya LKS merupakan bentuk usaha guru untuk membimbing siswa secara terstruktur, dimana kegiatan pembelajaranya memberikan daya tarik kepada siswa untuk mempelajari matematika. Agar siswa memiliki rasa ingin tahu yang lebih mendalam pada pembelajaran matematika sebagai seorang pendidik perlu melakukan variasi dalam menggunakan sumber belajar, oleh karena itu perlu adanya pengembangan LKS lebih kreatif dan tidak sama seperti biasanya (Gitriani, Aisah, Hendriana, \& Herdiman, 2018). Rendahnya rasa ingin tahu siswa terhadap pembelajaran tersebut salah satunya disebabkan karena kurangnya interaksi antar siswa dengan bahan ajar, dan terkadang matematika sulit dipahami oleh siswa karena proses pembelajaran didalam kelas cendrung kaku dan kurang menyenangkan (Rusliah, 2016)

Berdasarkan hasil observasi yang dilakukan di SMP Negeri 4 Sungai Penuh dengan wawancara dan pengamatan langsung. Proses pembelajaran di kelas VII sangat terlihat jelas bahwa tidak sedikit dari siswa tersebut kurang menyukai pelajaran matematika, sebagian dari merekapun masih mengangap pelajaran matematika itu adalah pelajaran yang sulit bahkan membuat mereka bingung dan membosankan. Siswa cendrung hanya menghapal, serta hanya menerima dan menggunakan rumus-rumus yang sudah ada dibuku cetak lalu mengerjakan soalsoal latihan yang menurut mereka sulit tanpa adanya dihubungkan dengan kehidupan sehari-hari, tanpa mengetahui banyak manfaat mereka mempelajarai materi yang diajarakan, Selain itu dalam proses pembelajaran sumber belajar yang digunakan hanya menggunakan buku paket, dibantu oleh bahan ajar lain yaitu 
seperti LKS sehingga pembelajaran kurang bermakna.

Pada hakikatnya sebagai seorang tenaga pendidik dapat memberikan suatu alternatif model pembelajaran yang menarik dan menunjang tumbuhnya kegiatan pembelajaran yang berpusat pada siswa sehingga tujuan yang direncanakan berhasil dicapai (Depdiknas, 2008). Pendekatan pembelajaran dapat berupaya membantu siswa menjadi aktif untuk mengembangkan daya nalar serta mampu mengembangkan dan mengevaluasi argumentasi, salah satu pendekatan yang dapat memenuhi tuntutan tersebut adalah model CTL dengan pendidikan lingkungan.

Contextual teaching and learning (CTL) adalah suatu pendekatan pembelajaran yang menekankan kepada proses keterlibtan siswa untuk menemukan materi yang dipelajari dan mengubungkan dengan kehidupan sehari-hari sehingga mendorong siswa untuk menerapkanya kedalam kehidupan nyata mereka (Sanjaya, 2005). CTL adalah model pembelajaran yang menjadikan siswa mampu mengaitkan materi pembelajaran dengan penerapanya dalam kehidupan sehari-hari (Yulia \& Ningsih, 2018). Pendekatan pembelajaran ini melibatkan tujuh komponen utama pembelajaraan yaitu konsruktivisme, bertanya, inquiry (menyelidiki, menemukan), masyarakat belajar, pemodelan, penilaian auntentik dan refleksi. Dengan 7 komponen tersebut model CTL diharapkan dapat menuntut siswa lebih produktif dan belajar melalui proses mengalami bukan menghapal (Yulia \& Sunggu, 2016).

Pendidikan lingkungan adalah pendidikan yang menggunakan pembelajaran yang membantu peserta didik untuk memahami lingkungan hidup dengan tujuan akhir agar siswa memiliki keperdulian untuk menjaga dan melestarikan lingkungan dan sikap bertangung jawab dan yang memupuk keinginan serta memiliki keterampilan untuk melestarikan lingkungan baik itu lingkungan sosial dan lingkungan alam, agar tercipta suatu sistem kehidupan bersama (Dewi, 2015).

Jadi diharapkan bahwa LKS berbasis Contextual Teaching and Learning (CTL) dengan Pendidikan Lingkungan ini dapat mengaktifkan siswa dalam proses pembelajaran yaitu mengaitkan pembelajaran dengan pengetahuan awal yang dimiliki melalui lingkungan sekitar dan kehidupan sehari, mengaitkan pembelajaran dengan stiuasi lingkungan siswa, memotivasi siswa dengan menyediakan kegiatan matematika atau tuga serta soal-soal matematika yang berhubungan dengan kehidupan sehari-hari Selain itu diharapkan mampu meningkatkan pemahaman siswa, tidak 
mengharuskan siswa menghapal rumusrumus. Tetapi pendekatan yang mendorong pembelajaran yang mengaitkan antara materi yang dipelajari dengan dunia nyata atau kehidupan seharihari yang memberikan pengalaman yang membuat siswa lebih peduli terhadap lingkungan dan menjaga kelestarian lingkungan.

Dari permasalahan di atas sehingga membuat peneliti tertarik untuk melakukan penelitian denga judul “ Pengembangan lembar kerja siswa (LKS) berbasis contextual teaching and Learning (CTL) dengan pendidikan lingkungan". Berdasarkan masalah dikemukakan pada latar belakang maka tujuan dari penelitian untuk menghasilkan dan mengetahui Lembar Kerja Siswa (LKS) berbasis Contextual Teaching and Learning (CTL) Dengan Pendidikan Lingkungan yang layak digunakan dalam pembelajaran matematika pada pokok bahasan Himpunan.

\section{Metode Penelitian}

Pada penelitian ini menggunakan metode Research and Development (R\&D) salah satu suatu desain penelitian yang mempunyai tujuan untuk meneliti, merancang memproduksi, mengembangkan dan mevalidasi suatu produk pendidikan yang diciptakan (Fiska
Komala Sari , Farida, 2016). Penelitian ini bertujuan untuk menghasilkan suatu produk berupa Lembar Kerja Siswa (LKS) berbasis Contextual Teaching and Learning (CTL) dengan Pendidikan Lingkungan pada materi Himpunan di Kelas VII SMP N 4 Sungai Penuh.

Desain penelitian yang digunakan dalam penelitian dan pengembangan ini adalah menggunakan model pengembangan ADDIE yang dikembangkan oleh Dick and Carry (1996). ADDIE merupakan konsep sebuah pengembangan produk yang mempunyai 5 tahapan, singkatan dari analysis, design, development, implementation, evaluation (Branch,2009). Teknik pengumpulan data pada penelitian ini dikumpulkan melalui validasi, wawancara tak terstruktur dan angket. Validasi yang dilakukan oleh tiga orang validator yang terdiri dari validator ahli materi, ahli media dan ahli bahasa. Validitas dari produk LKS yang dikembangkan dapat ditentukan berdasarkan kriteris berikut.

Tabel 1. Kriteria Presentase Validitas

\begin{tabular}{cc}
\hline Presentase & Kriteria \\
\hline $0 \%-20 \%$ & Sangat Kurang \\
\hline $21 \%-40 \%$ & Kurang \\
\hline $41 \%-60 \%$ & Cukup \\
\hline $61 \%-80 \%$ & Baik/ Valid \\
\hline $81 \%-100 \%$ & Sangat Baik/ Sangat Valid \\
\hline Sumber : (Putri \& Madlazim, 2017)
\end{tabular}




\section{Hasil dan Pembahasan}

Hasil dari penelitian dan pengembangan ini berupa sebuah produk Lembar Kerja Siswa Berbasis Contextual Teaching and Learning (CTL) Dengan Pendidikan Lingkungan pada materi himpunan yang valid dan layak digunakan melalui empat tahap yang diadaptasi dari langka-langkah penelitian dan pengembangan model ADDIE yaitu tahap analisis (analysis), tahap perancangan (design), tahap pengembangan dan pembuatan produk (development), tahap implementasi (implementasi) dan tahap evaluasi (evaluation) yang dikembangkan oleh oleh Dick dan Carry, 1996.

\section{Tahap Analysis (Analisis)}

Pada tahap ini ada beberapa aspek yang dianalisis yaitu:

\section{a. Hasil Analisis Kebutuhan}

Berdasarkan observasi langsung didalam kelas dan wawancara dengan salah satu guru matematika kelas VII SMPN 4 Sungai Penuh ditemukan bahwa bahan ajar yang digunakan saat proses pembelajaran hanya mengunakan buku paket tanpa dibantu oleh bahan ajar yang lain yaitu seperti LKS Oleh karena itu perlunya dikembangkan bahan ajar yang dapat membangun pengetahuan awal siswa, menemukan sendiri konsep mengenai materi, berpusat kepada siswa, membuat siswa aktif, siswa dapat saling bekerja sama dalam diskusi, mempresentasikan hasil diskusi di depan kelas dan agar siswa lebih peduli terhadap lingkungan sekitar dan pembelajaran lebih bermakna dan materi yang dipilih adalah materi himpunan karena pada materi ini sebagian besar siswa sering sulit memahami materi tersebut.

\section{b. Hasil Analisis Kurikulum}

Pada tahap ini dilakukan telaah kurikulum yang digunakan di SMPN 4 Sungai Penuh yaitu kurikulum K13, analisis kurikulum yang dimaksud adalah analisis terhadap indikator pencapaian kompetensi pada materi himpunan. K13 sebagai acuan sebagai dasar pengembangan LKS dan analisis kurikulum tidak ada perubahan KI, KD serta indikator kompetensi inti yang digunakan pada pengembangan LKS dan sesuai dengan silabus.

\section{c. Hasil Analisis Kebutuhan}

Pada tahap analisis karakter siswa dilakukan pengumpulan informasi mengenai fakta serta permasalahan yang ada pada saat proses pembelajaran matematika dan penyebabnya, pelaksanaan pembelajaran Berdasarkan hasil wawancara yang dilakukan dengan salah satu guru matematika kelas VII SMPN 4 Sungai Penuh hasil yang diperoleh dalam proses pembelajaran diketahui bahwa kemampuan yang dimilki oleh siswa bervariasi sehingga dibutuhkan bahan ajar 
yang yang cocok dan mudah dipahami untuk semua siswa, metode yang digunakan saat proses pembelajaran belum terlalu bervariasi serta pada angket pendahuluan persepsi siswa diketahui bahwa tidak sedikit dari siswa tersebut kurang menyukai pelajaran matematika, sebagian dari merekapun masih mengangap pelajaran matematika itu adalah pelajaran yang sulit bahkan membuat mereka bingung dan membosankan. Dan bahan ajar yang digunakan kurang menarik karena kurang berwarna dan tidak dikaitkan dengan kehidupan nyata.

Siswa menyukai warna merah, kuning biru dan mereka lebih suka pada sumber ajar yang menarik dan disajikan dengan warna yang bervariasi, kalimat dan kata yang mudah dipahami sehingga dapat membuat siswa senang dalam proses pembelajaran. Maka dapat disimpulkan bahwa siswa membutuhkan sumber ajar yang dapat mengatasi permasalahan di atas seperti LKS yang membuat pembelajaran lebih efektif dan proses pembelajaran akan lebih efektif dan bermakna jika siwa bisa mengeluarkan pengetahuan yang dimilikinya dan sesuai dengan tingkat perkembangannya serta menemukan sendiri konsep materi yang dipelajari serta disajikan dengan tampilan yang menarik.

\section{Tahap Design (Perancangan)}

\section{a. Persiapan Pembuatan Produk}

Pada tahap ini peneliti mengumpulkan, memilih dan memilah beberapa referensi yang digunakan untuk mendukung isi materi himpunan dari LKS yang akan disusun dan dikembangkan. Buku-buku refrensi menjadi bahan ajar yang saling melengkapi dan memperkaya isi dari LKS yang dikembangkan.

\section{b. Penyusunan Kerangka Dasar LKS}

Pada tahap ini membuat judul LKS sesuai dengan materi yang dipilih dan model yang akan digunakan pada pengembangan LKS, menuliskan draft LKS seperti KI dan KD, menuliskan dan merumuskan materi pokok himpunan yang terdiri dari 7 sub bab, menyusun variasi aktivitas yang akan dilakukan siswa serta merancang alat evaluasi dan membuat detail LKS seperti bagian pembuka, bagian isi dan bagian penutup.

\section{Tahap Development (Pengembangan} dan pembuatan produk)

\section{a. Tahap Validasi}

Tahap validasi Lembar Kerja Siswa (LKS) Berbasis Contextual Teaching and Learning (CTL) dengan Pendidikan Lingkungan dilakukan oleh 3 orang validator yaitu tiga orang dosen pendidikam matematika yang ahli dan kompoten dibidangnya yaitu Bapak Aan Putra, M.Pd sebagai ahli materi, Ibu Reri 
Seprina Anggraini, M.Pd sebagai ahli media dan Ibu Eline Yanty Putri Nasution, M.Pd sebagai ahli bahasa. Validasi dilakukan secara manual dengan validator dilakukan beberapa kali validasi sampai dengan produk yang dikembangkan dinyatakan valid atau layak digunakan.

Kriteria kevalidan LKS dinilai dari berbagai aspek yaitu, aspek kelayakan isi, aspek penyajian dan tampilan atau media, aspek kebahasaan. Setelah melakukan validasi dengan manual sampai beberapa kali dengan validator sampai mengatakan bahwa produk LKS yang dikembangkan valid dan diperoleh kesimpulan berdasarkan persentase kevalidan LKS disetiap aspek. Hasil validasi LKS Berbasis CTL dengan Pendidikan Lingkungan diuraikan sebagai berikut:

\section{1) Hasil Validasi LKS Ahli Materi}

Setelah divalidasi oleh ahli materi dibeberapa bagian LKS telah mengalami perbaikan atau revisi sesuai saran-saran dari validator. Berikut akan dipaparkan beberapa perubahan setelah dilakukan perbaikan.

Contoh pada LKS halaman 2 petunjuk masih belum jelas, dan sudah diperbaiki serta diperjelas. Lembar penilaian auntentik disetaip akhir bab belum menuliskan kriteria penilaian, dan sudah diperbaiki serta ditambahkan kriteria penilaian. Rumus pada materi banyaknya anggota himpunan diberikan tanpa ada proses dan setelah diperbaiki diberi proses untuk menemukan rumus menghitung banyaknya anggota himpunan dihubungkan dengan dunia nyata dan lingkungan sekitar sehingga rumus atau konsep ditemukan.

Selain itu, konsep irisan himpunan langsung diberikan tanpa ada proses penemuan, Setelah diperbaiki diberi proses dengan mengaitkan nya melaui kehidupan sehari-hari dan lingkungan untuk merangsang kemampuan awal yang dimiliki siswa menemukan konsep irisan himpunan sendiri. Cara menentukan dan rumus banyaknya anggota dari gabungan dua himpunan diberikan tanpa ada proses penemuan, setelah diperbaiki diberikan proses untuk menemukan konsep dan rumus banyaknya anggota dari gabungan dua himpunan

Kelayakan aspek materi LKS Berbasis CTL dengan Pendidikan Lingkungan yang berjumlah 26 butir uji, dari hasil penilaian dari validator dapat dilihat pada tabel 2 di bawah ini:

Tabel 2. Hasil validasi oleh validator

\begin{tabular}{ccc}
\hline Validator & $(\boldsymbol{\%})$ & Kriteria \\
\hline Materi & $85,57 \%$ & Sangat valid \\
\hline
\end{tabular}

\section{2) Hasil Validasi LKS Ahli Media}

Setelah divalidasi oleh ahli media dibeberapa bagian LKS telah mengalami perbaikan atau revisi sesuai saran-saran 
dari validator. Berikut akan dipaparkan beberapa perubahan setelah dilakukan perbaikan.

Pada halaman tiga tidak perlu dijawab siswa lagi jika jawabanya sudah ada, maka jawaban yang seharusnya tidak diberikan sudah dihapus. Gambar untuk kolom kesimpulan setelah mempelajari materi yang telah dipelajari masih belum jelas fungsinya, dan sudah diperbaiki serta memperjelas fungsi kolom kesimpulan. Warna latar, tulisan pada kolom contoh dan solusi matematika disemua bab LKS terlalu bewarna dan membuat sakit mata, setelah diperbaiki mengunakan warna pigir kolom saja.

Selanjutnya, halaman 45 belum memberikan soal latihan yang berkaitan dengan lingkungan dan ganti soal no 3 karena sulit dipahami, Hampir setiap latihan diberikan soal yang berkaitan dengan kehidupan sehari-hari dan lingkungan sekitar dan soal lingkungan sekitar dan soal no 3 juga sudah dirubah menjadi soal yang mudah dipahami

Kelayakan aspek media LKS Berbasis CTL dengan Pendidikan Lingkungan yang berjumlah 21 butir uji, dari hasil penilaian dari validator dapat dilihat pada tabel $3 \mathrm{di}$ bawah ini:

Tabel 3. Hasil validasi oleh validator

\begin{tabular}{ccc}
\hline Validator & $(\boldsymbol{\%})$ & Kriteria \\
\hline Media & $85,71 \%$ & Sangat valid
\end{tabular}

\section{3) Hasil Validasi Ahli Bahasa}

Setelah divalidasi oleh ahli Bahasa dibeberapa bagian LKS telah mengalami perbaikan atau revisi sesuai saran-saran dari validator. Berikut akan dipaparkan beberapa perubahan setelah dilakukan perbaikan.

Masih banyak penulisan huruf kapital yang belum tepat, setelah diperbaiki penulisan huruf kapital sudah sesuai. Pada sebagian besar LKS penulisan kata depan dan kata sambung masih salah, setelah diperbaiki penulisan kata sambung dan kata depan pada LKS sudah tepat. Penulisan tanda tanya masih belum tepat dan seharusnya tidak ada spasi sebelum tanda tanya, setelah diperbaiki penulisan tanda tanya sudah sesuai

Kelayakan aspek bahasa LKS Berbasis CTL dengan Pendidikan Lingkungan yang berjumlah 19 butir uji, dari hasil penilaian dari validator dapat dilihat pada tabel $4 \mathrm{di}$ bawah ini:

Tabel 4. Hasil validasi oleh validator

\begin{tabular}{ccc}
\hline Validator & $(\boldsymbol{\%})$ & Kriteria \\
\hline Bahasa & $94,73 \%$ & Sangat valid \\
\hline
\end{tabular}

\section{b. Hasil Uji Coba Perorangan}

Uji coba perorangan, pada tahap ini dilakukan pada satu guru yang berkompoten dibidangnya yaitu guru matematika kelas VII A Ibuk Yuresmi, 
S.Pd guna untuk memperoleh masukan tentang LKS yang dikembangkan. Setelah diuji cobakan peneliti melakukan wawancara bersama guru yang bersangkutan seputar LKS yang dikembangkan.

Menurutnya Secara umum LKS ini sudah mudah dipahami dan digunakan, proses pembelajaran dengan menggunakan LKS juga membuat pembelajaran lebih berpusat kepada siswa sehingga proses pembelajaran dirasakan lebih bermakna. tugas dan soal-soal sudah mewakili tujuan yang ingin dicapai, penggunaan kalimatnya pun komunikatif, mudah dipahami apalagi contoh ataupun materi yang dikaitkan dengan kehidupan seharihari dan lingkungan sekitar dapat merangsang pengetahuan awal siswa untuk menemukan konsep.

Namun ada beberapa penggunaan kata yang salah pada latihan seperti "kata besar dari", kecil dari" seharusnya kata tersebut diganti dengan "lebih dari" dan "kurang dari" dan materi yang disajikan di LKS sudah sesuai dengan KI, KD dan indikator pencapaian kompetensi.

\section{c. Hasil Uji Coba Kelompok Kecil}

Pada tahap ini LKS diujicobakan secara terbatas pada kelompok kecil saja yang terdiri dari 6 orang. Uji coba klompok kecil dimulai dari tanggal 29 September sampai dengan 5 Oktober 2020 materi pelajaran yang dipelajari yaitu sifatsifat himpunan dan irisan himpunan.

Setelah dijelaskan oleh guru secara singkat siswa yang telah ditunjuk untuk mengerjakan LKS sesuai dengan pemahaman dan kemampuannya masingmasing. Selama siswa mencoba mengerjakan LKS, peneliti memperhatikan apa yang dikerjakan oleh siswa dan mencatat apa saja yang terjadi ataupun kendala selama pengerjaan LKS. Setelah di uji cobakan kepada siswa yang mempunyai kemampuan yang bervariasi ternyata LKS dapat dengan mudah digunakakan dan dipahami oleh siswa terlihat jelas pada latihan yang dikerjakan oleh siswa dan proses pembelajaran menjadi aktif, menyenangkan dan berpusat pada siswa sehingga materi yang dibahasa karena ditemkan sendiri konsepnya oleh siswa maka akan lebih diingat materi yang telah dipelajari.

Setelah dilakukan uji coba peneliti melakukan wawancara pada semua siswa yang mengikuti uji coba kelompok kecil guna untuk memberikan masukan ataupun saran mengenai produk LKS yang telah digunakan siswa, dari hasil wawancara tersebut secara umum siswa menjelskan bahwa mereka sangat suka belajar matematika dengan menggunakan LKS ini serta menumbuhkan minat ataupun rasa ingin tahu terhadap materi himpunan yang dipelajari hal tersebut karena LKS ini 
sangat mudah dipahami, pengemasan tugas, penjelasan ataupuncontoh soal pada LKS dapat menarik perhatian mereka.

Merekapun mengatakan bahwa dengan menggunakan LKS ini mereka terbiasa menemukan konsep sendiri yang dikaitan dengan kehidupan sehari-hari dan lingkungan, membuat mereka menjadi lebih aktif dan berani menyampaikan pendapat, dapat mendorong mereka untuk bertanya, melalui pngemasan tugas, contoh soal yang dikaitkan dengan kehidupan sehari-hari dan penekanan terhadap pendidikan lingkungan membuat mereka lebih sadar dan peduli terhadap lingkungan sekitar karena mereka mendapat informasi baru mengenai gerakan peduli lingkunga, manfaat materi himpunan pada pengelompokan sampah yang dapat memudahkan petugas kebersihan dan lain sebagainya dan merekapun mengharapakan bahwa untuk mata pelajaran lain diberikan dengan mengunakan LKS seperti yang digunakan saat ini.

Mereka juga suka mengenai tampilan pada LKS secara keseluruhan karena semua yang disajikan pada LKS adalah berdasarkan keinginan mereka dan tidak ada bagian LKS yang membuat mereka bingung ataupun sulit untuk memahaminya namun ada saran perbaikan dari siswa mengenai LKS ini yaitu tabel kolom untuk mengerjakan tugas halaman
38 diharapkan lebih besar agar muat untuk siswa menjawab pertanyaan yang ada. Peneliti pun merevisi sesuai dengan keinginan siswa agar LKS yang dikembangkan lebih baik lagi.

Perangkat pembelajaran dikatakan valid apabila validasi ahli dilakukan dengan cara seorang atau beberapa ahli pembelajaran memberi penilaian melalui instrumen validasi ahli sesuai dengan pendapat sugiono bahan ajar dikatakan valid apabila menghadirkan beberapa pakar atau tenaga ahli yang sudah berpengalaman untuk menilai produk baru yang dirancang tersebut (Sugiono, 2016).

Keungulan LKS berbasis CTL dengan Pendidikan Lingkungan in karena sudah sesuai dengan fungsi, tujuan dan manfaat penyusunan dan pengembangan LKS yang baik karena LKS ini dikembangkan sudah berdasarkan analisis kebutuhaan siswa LKS ini dapat memuat tujuan, fungsi dan manfaat LKS yang baik karena LKS yang dikembangkan ini menggunakan pendekatan CTL dengan pendidikan lingkungan yang membuat proses pembelajaran berpusat kepada siswa, menemukan konsep materi yang dipelajari sendiri, membuat proses pembelajaran menjadi bermakna, penyajian dan tampilan LKS yang dikembangkan sesuai dengan keinginan dan kebutuhan siswa sehingga mendorong siswa menjadi bersemangat untuk belajar dengan menggunakan LKS 
ini, membuat siswa lebih aktif, membuat siswa ingin tahu terhadap materi yang dipelajaari dan membuat pembelajaran matematika lebih menyenangkan bagi siswa.

Sesuai dengan penelitian (Apriani, Buyung, \& Relawati, 2017) mereka juga mengembangkan LKS berbasis CTL yang sesuai dengan karakteristik, lingkungan sosial siswa, serta dapat mengaktifkan siswa selama proses pembelajaran yang dihubungkan dengan kehidupan sehari-hari sehingga dapat membantu siswa memahami kegunaan materi dalam kehidupan sehari-hari. Dengan mengajar dunia nyata melalui pembelajaran matematika kita dapat mengubah persfektif siswa tentang matematika itu tidak hanya meningkatkan kompleksitas pemahamaman siswa tentang matematika tetapi juga dapat meningkatkan minat siswa (Gutstein, 2003)

Pendidikan lingkungan adalah pendidikan yang berpusat pada siswa, memberikan siswa kesempatan untuk membangun pemahaman mereka sendiri melalui investigasi langsung yang melibatkan pikiran siswa dalam pengalaman langsung dan menantang mereka untuk menggunakan pemikiran tingkat tinggi (Habibi, 2015).

\section{Kesimpulan}

Penelitian ini merupakan penelitian yang menghasilkan Lembar Kerja Siswa (LKS) berbasis Berbasis Contextual Teaching and Learning (CTL) dengan Pendidikan Lingkungan Kesimpulan yang dapat diperoleh dari penelitian pengembangan ini adalah Lembar Kerja Siswa (LKS) berbasis Berbasis Contextual Teaching and Learning (CTL) dengan Pendidikan Lingkungan dikembangkan melalui empat tahapan yang diadaptasi dari penelitian dan pengembangan model ADDIE.

Empat tahap tersebut adalah tahap Analisis (Analysis) pada tahap inidilakukan analisis kebutuhan, analisis kurikulum dan analisis siswa dengan cara mengumpulkan informasi fakta dan permasalahan yang dirasa bisa mendukung untuk tahap selanjutnya. Tahap Perancangan (Design) pada tahap ini dilakukan tahap persiapan pembuatan produk, dan penyusunan kerangka dasar LKS selain itu dirancang juga instrumen penelitian yang akan digunakan pada penelitian. Tahap Pengembangan dan pembuatan produk (Developmen), pada tahap ini dilakukan uji validitas dengan 3 orang dosen yang ahli dan kompoten dibidangnya yaitu ahli materi, ahli media dan ahli bahasa dan dinyatakan bahwa produk yang dikembangkan valid, uji coba 
perorangan dilakukan dengan guru yang berpengalaman dan kompoten dibidangnya. Uji coba perorangan dilakukan guna mendapatkan saran perbaikan pada LKS yang dikembangkan. Sedangkan uji coba kelompok kecil yang terdiri dari 6 siswa. Berdasarkan hasil analisis LKS Berbasis Contextual Teaching and Learning (CTL) dengan Pendidikan Lingkungan yang dihasilkan dari penelitian ini sudah memenuhi kualitas produk yang valid dan layak digunakan.

\section{Pustaka}

Apriani, Buyung, \& Relawati. (2017). Pengembangan Lembar Kerja Siswa (LKS) Berbasis Contextual Teaching and Learning (CTL) Pada Materi Faktorisasi Suku Aljabar Kelas VIII SMP Negeri 9 Muaro Jambi. Jurnal Pendidikan Matematika, 1(1).

Branch, Robert Maribe. (2009). "Instructional Design : The ADDIE Approach". Springer New York Dordrecht Heidelberg London.

Dewi, D. A. (2015). Matematika Hijau Sebagai Salah Satu Upaya Pendidikan Karakter Berwawasan Lingkungan. Math Didactic: Jurnal Pendidikan Matematika, 1(1), 33-38.

Fatimah, A. E., \& Purba, A. (2018). Pengembangan Lembar Aktivitas
Siswa (LAS) Menggunakan Pendekatan Differentiated Instruction Untuk Meningkatkan Kemampuan Pemecahan Masalah Matematis Siswa SMK. MES (Journal of Mathematics Education and Science), 4(1), 1-9.

Fiska Komala Sari, Farida, M. S. (2016). Pengembangan Media Pembelajaran (Modul) berbantuan Geogebra Pokok Bahasan Turunan. Jurnal Pendidikan Matematika, 7(2), 135-152.

Gitriani, R., Aisah, S., Hendriana, H., \& Herdiman, I. (2018). Pengembangan lembar kerja siswa berbasis pendekatan kontekstual pada materi lingkaran untuk siswa smp. Jurnal Review Pembelajaran Matematika, 3(2), 40-48.

Gutstein, E. (2003). Teaching and Learning Mathematics for Social Justice in an Urban, Latino School. Journal for Research in Mathematics Education, 34(1), 37-73.

Habibi, M. (2015). Environment Education In Mathematics Classroom: As an Effort to Develop the Critical Thinking Skills and for Environmental Sustainability Concerning. (May). https://doi.org/10.13140/RG.2.1.2700 .0486

Hanifah, F. N. (2017). Jurnal Inovasi Pendidikan Fisika ( JIPF) ISSN : 2302-4496 Fikria Norma Hanifah 
Abstrak Fikria Norma Hanifah Jurnal Inovasi Pendidikan Fisika ( JIPF ) ISSN : 2302-4496 Fikria Norma Hanifah. Jurnal Inovasi Pendidikan Fisika (JIPF), 06(03), 60-66.

Islami, A., \& Rusliah, N. (2019). Pengaruh Self Confidence Terhadap Pemahaman Konsep Matematis Siswa Sekolah Menengah Pertama. Prosiding Seminar Nasional Integrasi Matematika Dan Nilai Islami, 3(1), 187-193.

Putri, W. R., \& Madlazim. (2017).

Pengembangan LKS Bounded Inquiry

Berbasis Laboratorium Nyata dan Laboratorium Virtual Untuk Melatihkan Kompetensi Literasi SAINS-FISIKA Pada Materi Global Warming. Jurnal Inovasi Pendidikan Fisika (JIPF), 06(03), 36-43.

Rawa, N. R. (2020). Pengembangan Lembar Kegiatan Siswa (LKS) Matematika Berbasis Pendekatan Scientific pada Materi Aritmatika Sosial bagi Siswa SMP. Jurnal Kependidikan, 6(2), 319-328.

Rusliah, N. (2016). Pendekatan Etnomatematika dalam Permainan Tradisional Anak di Wilayah Kerapatan Adat Koto Tengah Kota Sungai Penuh Propinsi Jambi. ICON UCE, 2-5.

Santoso, G., Yulia, P., \& Rusliah, N. (2020). Validitas Lembar Kerja
Peserta Didik (LKPD) Berbasis Etnomatematika pada Materi Geometri dan Pengukuran. PYTHAGORAS: Journal of the Mathematics Education Study Program, 9(2), 165-172.

Setiawan, W. (2015). Meningkatkan Kemampuan Berpikir Kritis Matematis Siswa SMP Dengan Model Penemuan Terbimbing. Jurnal Ilmiah UPT P2M, 2(1), 91-97.

Sudjana dan Rifai Ahmad. (2002). "Media Pembelajaran”. Bandung: Sinar Baru, Algenindo.

Sugiyono. (2016)." Metode Penelitian dan Pengembangan (Research and Development/R\&D). Bandung : Alfabeta.

Vera, T. O., Yulia, P., \& Rusliah, N. (2021). Peningkatan Kemampuan Pemecahan Masalah Matematis Melalui Model Problem Based Learning dengan Menggunakan Soalsoal Berbasis Budaya Lokal. Logaritma: Jurnal Ilmu-ilmu Pendidikan dan Sains, 9(01), 1-14.

Yulia, P. (2016). Efektifitas Model Pembelajaran CTL (Contextual Teaching And Learning) Terhadap Kemampuan Pemecahan Masalah Matematis Siswa Kelas VIII SMP N 16 Batam Tahun Pelajaran 2014/2015. PYTHAGORAS: Journal of the Mathematics Education Study 
Program, 5(1).

Yulia, P. (2016). Pengembangan Perangkat

Pembelajaran Berbasis Problem

Based Learning (PBL) untuk Kelas V

SD. In Jurnal Seminar Nasional (Vol.

1, No. 1, pp. 172-179).

Yulia, P., \& Ningsih, S. U. (2018).

Pengaruh Penerapan Model

Pembelajaran Probing Prompting dan

Contextual Teaching and Learning

Terhadap Hasil Belajar Ditinjau dari

Motivasi Belajar Siswa Sekolah

Menengah Kejuruan. Edumatika:

Jurnal Riset Pendidikan

Matematika, 1(1), 56-62.

Yulia, P., Febriza, E., \& Erita, S. (2021).

Development Of Etnomathematics

Based Flat Building Handouts for

Students Class VII SMP. Mathline:

Jurnal Matematika dan Pendidikan

Matematika, 6(2), 207-221.. 
